\title{
Determination of lethal concentration and antibacterial activity of commonly used disinfectants
}

\author{
Alam M, Rahman MM*, Foysal MJ and Hossain MN \\ Department of Genetic Engineering and Biotechnology, \\ Shahjalal University of Science and Technology, Sylhet-3114, Bangladesh
}

[Received: November 26, Accepted: December 27, 2011]

\begin{abstract}
The toxic effects of four disinfectants viz., copper sulfate $\left(\mathrm{CuSO}_{4}\right)$, potassium permanganate $\left(\mathrm{KMnO}_{4}\right)$, methylene blue and malachite green on fish and fish pathogenic bacteria Aeromonas sp., Pseudomonas fluorescens, Edwardsiella sp. and Flavobacterium sp. were investigated. Lethal concentration of the disinfectants to fingerlings of Labeo rohita was determined in aquarium by standard method. Lethal concentration of copper sulfate $\left(\mathrm{CuSO}_{4}\right)$, potassium permanganate $\left(\mathrm{KMnO}_{4}\right)$, methylene blue and malachite green against fish were found in $0.75 \mathrm{ppm}, 7 \mathrm{ppm}, 6 \mathrm{ppm}$ and $0.5 \mathrm{ppm}$ at $21.4 \mathrm{hrs}, 18 \mathrm{hrs}, 9.5 \mathrm{hrs}$ and $1.40 \mathrm{hrs}$, respectively. Methylene blue at $4 \mathrm{ppm}$ and $5 \mathrm{ppm}$ concentration inhibited the growth of Pseudomonas fluorescens and $6 \mathrm{ppm}$ concentration suppressed the growth of Aeromonas $\mathrm{sp}$. Copper sulfate $\left(\mathrm{CuSO}_{4}\right)$ was effective only against Edwardsiella sp at concentration of $10 \mathrm{ppm}$ and $8 \mathrm{ppm}$. Malachite green repressed the growth of all four tasted bacteria at a concentration of $1 \mathrm{ppm}$. Potassium permanganate $\left(\mathrm{KMnO}_{4}\right)$ was failed to exhibit any inhibitory effect on the bacteria even at 30 ppm concentration.
\end{abstract}

Keyword: Disinfectant, Lethal concentration, Fish pathogen, Antibacterial activity.

\section{INTRODUCTION}

In Bangladesh, large number of fish dies in different fish farms each year due to the outbreak of bacterial and fungal diseases ${ }^{[1]}$. The major bacterial fish diseases frequently occurred in fish farms of Bangladesh are motile Aeromonad septicaemia, bacterial haemorrhagic septicaemia, edwardsiellosis and columnaris disease (gill rot and tail and fin rot disease) which are caused by motile Aeromonas spp., Pseudomonas fluorescens, Edwardsiella spp. and Flavobacterium spp. , respectively [2, 3, 4 ,5]. As preventive and control measures of various fish diseases famers and hatchery owners use different kinds of disinfectants. Copper sulfate $\left(\mathrm{CuSO}_{4}\right)$, potassium permanganate $\left(\mathrm{KMnO}_{4}\right)$, methylene blue and malachite green are common chemicals used for eradication of external parasites and fungal diseases in fish ${ }^{[6,7]}$. Copper sulfate $\left(\mathrm{CuSO}_{4}\right)$ is an effective algaecide but it has toxic effect on many fish species. The factors influences the toxicity of copper is related to water quality characteristics such as hardness, alkalinity, $\mathrm{pH}$, and dissolved organic carbon ${ }^{[8]}$. Increases of these water quality parameters result in decreased copper toxicity and subsequent increase of tolerance by fish, while higher concentrations are required to control algae ${ }^{[9]}$. Potassium permanganate $\left(\mathrm{KMnO}_{4}\right)$ possesses toxicity for bacteria and phytoplankton and and are generally used to detoxify fish toxins such as rotenone and antimycin ${ }^{[10,11]}$. Methylene Blue is effective against superficial fungal infections of fishes since used against bacterial, fungal and parasite infections. It also kills plants and pond bio-filter bacteria. The drug may be used as an alternative to malachite green for the control of fungus when it is known that the fish to be treated are sensitive. Methylene blue is safe for use with fish eggs and fry for the prevention of fungal infections ${ }^{[12]}$. As a secondary use, it is effective against some external protozoan's, such as Ichthyophthirius, Chilodonella and Costia. Methylene blue was effective in reducing bacterial load in Tilapia (Orechromis niloticus) fingerlings ${ }^{[12]}$. Malachite green has been widely used for external infection of protozoan and fungal diseases since 1993 but due to its negative effect on fish and aquatic organisms yet it struggle to registered as veterinary drugs $[13,14,15]$. However, in Bangladesh the fish farmers do not know the proper doses of the disinfectants and often apply disinfectants at high doses which may lead toxic effects, even may cause mortality of fish. Unfortunately, no systematic study has yet been conducted to solve the problems. Considering the facts, the present study has been conducted to find out the toxic effects of four disinfectants viz., copper sulfate $\left(\mathrm{CuSO}_{4}\right)$, potassium permanganate $\left(\mathrm{KMnO}_{4}\right)$, methylene blue and malachite green on fish and fish pathogenic Aeromonas sp., Pseudomonas fluorescens, Edwardsiella sp. and Flavobacterium sp. bacterial isolates.

\section{MATERIALS AND METHODS}

Determination of Lethal Concentrations to Fish: 
Table 1. LC50 value of $\mathrm{CuSO}_{4}, \mathrm{KMnO}_{4}$, Methylene blue and Malachite green for Labeo rohita fingerlings.

\begin{tabular}{|c|c|c|c|}
\hline $\begin{array}{l}\text { Name of the } \\
\text { chemical }\end{array}$ & $\begin{array}{l}\text { Dose } \\
\text { (ppm) }\end{array}$ & Mortality rate (in time) & LC50 \\
\hline & $\begin{array}{l}\text { Control } \\
0.25\end{array}$ & $\begin{array}{l}0 \%(24 \mathrm{hrs}) \\
0 \%(24 \mathrm{hrs})\end{array}$ & \multirow[b]{3}{*}{ LC50 $=21.40 \mathrm{hrs}$} \\
\hline & 0.5 & $17 \%(18.10 \mathrm{hrs}), 33 \%(27.40 \mathrm{hrs})$ & \\
\hline $\mathrm{CuSO}_{4}$ & $\begin{array}{l}0.75 \\
1 \\
2 \\
3 \\
4 \\
5 \\
10 \\
20 \\
30\end{array}$ & $\begin{array}{l}33 \%(18.10 \mathrm{hrs}), 50 \%(21.40 \mathrm{hrs}) \\
17 \%(9.45 \mathrm{hrs}), 100 \%(10.15 \mathrm{hrs}) \\
17 \%(46 \mathrm{~min}), 100 \%(9.45 \mathrm{hrs}) \\
17 \%(30 \mathrm{~min}), 100 \%(9.30 \mathrm{hrs}) \\
17 \%(30 \mathrm{~min}), 33 \%(46 \mathrm{~min}), 100 \%(9 \mathrm{hrs}) \\
33 \%(30 \mathrm{~min}), 100 \%(7.50 \mathrm{hrs}) \\
100 \%(2.5 \mathrm{hrs}) \\
100 \%(1.30 \mathrm{hrs}) \\
100 \%(50 \mathrm{~min})\end{array}$ & \\
\hline \multirow{6}{*}{$\mathrm{KMnO}_{4}$} & $\begin{array}{l}\text { Control } \\
5\end{array}$ & $\begin{array}{l}0 \%(24 \mathrm{hrs}) \\
0 \%(24 \mathrm{hrs})\end{array}$ & \multirow{4}{*}{$\mathrm{LC} 50=18 \mathrm{hrs}$} \\
\hline & $\begin{array}{l}6 \\
7 \\
8\end{array}$ & $\begin{array}{l}17 \%(6.30 \mathrm{hrs}), 33 \%(12.45 \mathrm{hrs}), 50 \%(18 \mathrm{hrs}) \\
17 \%(5.30 \mathrm{hrs}), 33 \%(9.45 \mathrm{hrs}) 100 \%(21 \mathrm{hrs}) \\
100 \%(9.15 \mathrm{hrs})\end{array}$ & \\
\hline & 9 & $100 \%(6.30 \mathrm{hrs})$ & \\
\hline & $\begin{array}{l}10 \\
\text { Control }\end{array}$ & $\begin{array}{l}100 \%(3 \mathrm{hrs}) \\
0 \%(24 \mathrm{hrs})\end{array}$ & \\
\hline & $\begin{array}{l}5 \\
6\end{array}$ & 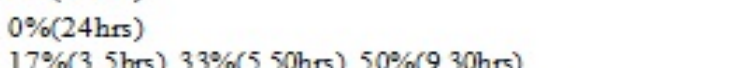 & \multirow{9}{*}{$\mathrm{LC} 50 /=.30 \mathrm{hrs}$} \\
\hline & 7 & $\begin{array}{l}33 \%(3.30 \mathrm{hrs}), 50 \%(6.45 \mathrm{hrs}), 67 \%(9.30 \mathrm{hrs}) \text {, } \\
83 \%(15.30 \mathrm{hrs})\end{array}$ & \\
\hline \multirow[t]{7}{*}{ Methylene blue } & 8 & $67 \%(9.30 \mathrm{hrs}), 83 \%(10.30 \mathrm{hrs}), 100 \%(18 \mathrm{hrs})$ & \\
\hline & 9 & $17 \%(20 \mathrm{~min}), 83 \%(8.50 \mathrm{hrs}), 100 \%(10.30 \mathrm{hrs})$ & \\
\hline & 10 & $83 \%(5.30 \mathrm{hrs}), 100 \%(8.45 \mathrm{hrs})$ & \\
\hline & 15 & $83 \%(3.15 \mathrm{hrs}), 100 \%(2.45 \mathrm{hrs})$ & \\
\hline & 20 & $100 \%(2.30 \mathrm{hrs})$ & \\
\hline & 30 & $100 \%(2 \mathrm{hrs})$ & \\
\hline & 40 & $100 \%(1.15 \mathrm{hrs})$ & \\
\hline \multirow[t]{6}{*}{ Malachite green } & Control & $0 \%(24 \mathrm{hrs})$ & \multirow{6}{*}{ LC50 $=1.40 \mathrm{hrs}$} \\
\hline & 0.1 & $0 \%(24 \mathrm{hrs})$ & \\
\hline & 0.25 & $17 \%(17 \mathrm{hrs})$ & \\
\hline & 0.5 & $33 \%(1 \mathrm{hr}), 50 \%(1.40 \mathrm{hrs}), 67 \%(2.40 \mathrm{hrs}), 100 \%(3.10 \mathrm{hrs})$ & \\
\hline & 0.75 & $67 \%(1 \mathrm{hr}), 83 \%(1.40 \mathrm{hrs}), 100 \%(2.40 \mathrm{hrs})$ & \\
\hline & 1 & $17 \%(15 \mathrm{~min}), 50 \%(30 \mathrm{~min}), 83 \%(45 \mathrm{~min}), 100 \%(5 \mathrm{~min})$ & \\
\hline
\end{tabular}

Determination of lethal concentration of disinfectants copper sulfate $\left(\mathrm{CuSO}_{4}\right)$, potassium permanganate $\left(\mathrm{KMnO}_{4}\right)$, methylene blue and malachite green were carried out in fish on aquarium, each of 30 liters water capacity. Individual aquarium was suspended with 6 liters of filtered water. Copper sulfate $\left(\mathrm{CuSO}_{4}\right)$ solution was prepared at $0.25 \mathrm{ppm}, 0.5 \mathrm{ppm}$, $0.75 \mathrm{ppm}, 1 \mathrm{ppm}, 2 \mathrm{ppm}, 3 \mathrm{ppm}$, 4ppm, 5ppm, 10ppm, $20 \mathrm{ppm}$ and $30 \mathrm{ppm}$ concentrations while potassium permanganate $\left(\mathrm{KMnO}_{4}\right)$ solution was prepared at 5ppm, 6ppm, 7ppm, 8ppm, 9ppm, 10ppm concentrations. The concentration of methylene blue was 5ppm, 6ppm, 7ppm, 8ppm, 9ppm, 10ppm, $15 \mathrm{ppm}, 20 \mathrm{ppm}, 30 \mathrm{ppm}, 40 \mathrm{ppm}$ and 50ppm. Doses of malachite green were $0.1 \mathrm{ppm}, 0.25 \mathrm{ppm}, 0.5 \mathrm{ppm}$, $0.75 \mathrm{ppm}$ and $1 \mathrm{ppm}$. The concentrations were adjusted by measuring the disinfectants in electric balance and dissolve in necessary volume of water. Each aquarium was marked with specific concentration of individual disinfectant. Six fingerlings of Labeo rohita with a size range of 8-10 $\mathrm{cm}$ were stocked in each aquarium and monitored at a regular interval.
Determination of Inhibitory Effects on Bacteria:

The detrimental activities of the disinfectants against representative of four genera of fish pathogenic bacteria viz., Aeromonas sp. isolate E22, Pseudomonas fluorescens isolate PuKL2, Edwardsiella sp. isolate Eds33and Flavobacterium sp. isolate Fxskin5 were determined in in vitro condition. At the beginning of the experiment the selected isolates were grown in nutrient broth for 24 hours into a shaker-incubator at $25^{\circ} \mathrm{C}$ with a rotation of $100 \mathrm{rpm}$. Approximately 50 $\mu 1$ of bacterial broth suspension was taken on nutrient agar plates inside a laminar air-flow cabinet and bacterial broth culture was spared with L-shaped glass rod by turning the plate clock wise and anti-clock wise. The glass rod was sterilized by sinking glass rod with $70 \%$ alcohol and flamed in spirit lamp. Solution of different concentrations of copper sulfate $\left(\mathrm{CuSO}_{4}\right)$, potassium permanganate $\left(\mathrm{KMnO}_{4}\right)$, methylene blue and malachite green were prepared in autoclaved distilled water. Then, $1 \mathrm{ml}$ of each solution was taken in individual micro centrifuge tube and $50 \mu$ of each solution was inoculated on the agar plate containing 
Table2. Antibacterial effect of Methylene blue, $\mathrm{CuSO}_{4}, \mathrm{KMnO}_{4}$ and Malachite green.

\begin{tabular}{|c|c|c|c|c|c|}
\hline Disinfectant & & $\begin{array}{l}\text { Aeromonas } \\
\text { sp.(E22) }\end{array}$ & $\begin{array}{l}\text { Pseudomonas } \\
\text { fluorescens (PuKL2) }\end{array}$ & $\begin{array}{l}\text { Edwardsiella sp. } \\
\text { (Eds33) }\end{array}$ & $\begin{array}{l}\text { Flavobacterium sp. } \\
\text { (Fxskin5) }\end{array}$ \\
\hline \multirow{3}{*}{$\begin{array}{l}\text { Methylene } \\
\text { blue }\end{array}$} & $4 \mathrm{ppm}$ & - & $13 \mathrm{ppm}$ & - & - \\
\hline & $5 \mathrm{ppm}$ & $16 \mathrm{~mm}$ & $15 \mathrm{ppm}$ & - & - \\
\hline & $6 \mathrm{ppm}$ & $20 \mathrm{~mm}$ & $20 \mathrm{ppm}$ & - & - \\
\hline \multirow[t]{3}{*}{$\mathrm{CuSO}_{4}$} & $5 \mathrm{ppm}$ & - & $6 \mathrm{~mm}$ & $11 \mathrm{~mm}$ & - \\
\hline & $8 \mathrm{ppm}$ & - & - & $7 \mathrm{~mm}$ & - \\
\hline & $10 \mathrm{ppm}$ & - & - & - & - \\
\hline \multirow[t]{4}{*}{$\mathrm{KMnO}_{4}$} & $15 \mathrm{ppm}$ & - & - & - & - \\
\hline & $20 \mathrm{ppm}$ & - & - & - & - \\
\hline & $30 \mathrm{ppm}$ & - & - & - & - \\
\hline & $0.1 \mathrm{ppm}$ & - & - & - & - \\
\hline \multirow{4}{*}{$\begin{array}{l}\text { Malachite } \\
\text { green }\end{array}$} & $0.25 \mathrm{ppm}$ & - & - & - & - \\
\hline & $0.5 \mathrm{ppm}$ & - & - & - & - \\
\hline & $0.75 \mathrm{ppm}$ & - & - & - & - \\
\hline & $1 \mathrm{ppm}$ & $7 \mathrm{~mm}$ & $6 \mathrm{~mm}$ & $8 \mathrm{~mm}$ & $8 \mathrm{~mm}$ \\
\hline
\end{tabular}

spread culture inoculums. The plate was remarked with solution concentration and bacterial isolate no. The plates were then kept in an incubator at $25^{\circ} \mathrm{C}$ for 12 hours. After 12 hours of incubation, the organism was considered sensitive if there was zone of complete inhibition around the inoculated solution. The organism was considered resistant if there was no zone of inhibition.

\section{RESULTS AND DISCUSSION}

Aquaculture is an important economic arena of Bangladesh. But, incidence of different diseases including the bacterial diseases limits the production of fish in aquaculture facilities. Different disinfectants are traditionally used for prevention and control of fish diseases. However these disinfectants are toxic ${ }^{[17]}$ and may even cause death of fish. In the present study, lethal concentration of copper sulfate $\left(\mathrm{CuSO}_{4}\right)$, potassium permanganate $\left(\mathrm{KMnO}_{4}\right)$, methylene blue and malachite green for fingerlings of Labeo rohita were found $0.75 \mathrm{mg} / \mathrm{L}, 7.00 \mathrm{mg} / \mathrm{L}$, $6.00 \mathrm{mg} / \mathrm{L}$ and $0.50 \mathrm{mg} / \mathrm{L}$ at $21.4 \mathrm{hrs}, 18.0 \mathrm{hrs}, 9.5$ hrs and $1.4 \mathrm{hrs}$, respectively. Bills $(1974)^{[16]}$ reported the $\mathrm{LC}_{50}$ value of malachite green to be $2 \mathrm{mh} / \mathrm{L}$ for rainbow trout fingerlings.

Inhibitory effects of four disinfectants to representative of four major bacterial fish pathogen was examined in in vitro condition. Experimental data suggested that Pseudomonas fluorescens isolate PuKL2 at $4 \mathrm{mg} / \mathrm{L}$ and $5 \mathrm{mg} / \mathrm{L}$ and Aeromonas sp. isolate E22 at $6 \mathrm{mg} / \mathrm{L}$ concentrations of methylene blue were unable to multiply. Edwardsiella sp. isolate Eds33 was inhibited by $10 \mathrm{mg} / \mathrm{L}$ and $8 \mathrm{mg} / \mathrm{L}$ $\mathrm{CuSO}_{4}$. Flavobacterium isolate Fxskin5 was found to be resistant to copper sulfate $\left(\mathrm{CuSO}_{4}\right)$, potassium permanganate $\left(\mathrm{KMnO}_{4}\right)$ and methylene blue at all concentrations but sensitive only against malachite green at $1 \mathrm{ppm}$ concentration. Potassium permanganate $\left(\mathrm{KMnO}_{4}\right)$ was failed to inhibit any of these four types of bacteria at all tested concentrations, whereas malachite green inhibits the growth of all of the bacteria at a concentration of $1 \mathrm{ppm}$. Only methylene blue was capable to eradicate Pseudomonas fluorescens and Aeromonas sp. bellow the lethal concentration. So, disease in fish associated with Pseudomonas fluorescens and Aeromonas sp. can be treated with methylene blue without any adverse effects on fish. ${ }^{[12]}$. Two important algaecides Copper sulfate $\left(\mathrm{CuSO}_{4}\right)$ and potassium permanganate $\left(\mathrm{KMnO}_{4}\right)$, were failed to show its efficacy bellow the lethal concentration. Copper sulfate $\left(\mathrm{CuSO}_{4}\right)$ was effective against Edwardsiella sp. isolate Eds33. at $10 \mathrm{ppm}$ and 8 ppm, far away from lethal concentrations $(0.75 \mathrm{mg} / \mathrm{L}$ at $21.4 \mathrm{~h})$. So, copper sulfate $\left(\mathrm{CuSO}_{4}\right)$ should not be used for prevention and control of fish disease associated with Edwardsiella spp. Potassium permanganate $\left(\mathrm{KMnO}_{4}\right)$ was ineffective to inhibit any of these four types' of bacteria even at $30 \mathrm{mg} / \mathrm{L}$ concentration. So, potassium permanganate $\left(\mathrm{KMnO}_{4}\right)$ should not be considered for health management of bacterial disease of fish.

\section{SUMMARY AND CONCLUSION}

The experiment was conducted to detect the lethal concentrations for fish and antibacterial activity of four commonly used disinfectants in Bangladesh. In the present study, it was found that some disinfectant specially methylene blue and $\mathrm{CuSO} 4$ were active against Aeromonas sp. and Pseudomonas fluorescens at lower than lethal concentration. Findings of the present study will be helpful for fish farmers for prevention and control of bacterial fish diseases.

\section{ACKNOWLEDGEMENTS}

This research work was conducted in the USDAProject laboratory of the Department of Genetic Engineering and Biotechnology, Shahjalal University 
of Science and Technology, Sylhet, Bangladesh which was established under the financial support of United States Department of Agriculture under a research project titled "Molecular Detection of Bacterial and Fungal Diseases of Carp and Fish and Herbal Treatment for Remedy of the Diseases".

\section{REFERENCES}

1. Rahman MM, Somseri T, Ezura Y and Tajima K (2005). PCR-RFLP analysis of Aeromonas isoltes collected from diseased fish and aquatic animals. Fish Pathol. 40(4):151-159.

2. Rahman MM and Hossain, MN (2010). Antibiotic and herbal sensitivity of some Aeromonas sp. collected from diseased carp fish. Progress. Agric. 21(1\&2):117-129.

3. Foysal MJ (2010). Identification, pathogenecity antibiotic and herbal sensitivity of Pseudomonas fluorescens isolated from diseased fish. B. Sc Thesis, Department of Genetic Engineering and Biotechnology, Shahjalal University of Science and Technology, Sylhet, Bangladesh. 94 pp.

4. Ferdowsy H, Foysal MJ, Hossain, MN and Rahman MM (2011). Isolation of Edwardsiella sp. from diseased catfish and their sensitivity to some antibiotics and medicinal plant extracts. Int. J. BioRes. 11 (1): 48-53.

5. Rahman MM, Ferdowsy H, Kashem MA and Foysal MJ (2010). Tail and fin rot disease of carp and climbing perch in Bangladesh. J. Biol. Sci. 10 (8): 800- 8004.

6. Faruk MAR, Ali MM and Patwary ZP (2008). Evaluation of the status of use of chemicals and antibiotics in fresh water aquaculture activities with special emphasis to fish health management. J. Bangladesh Agricul. Univ. 6(2):381-390.

7. Faruk MAR, Alam MJ, Sarker MMR and Kabir MB (2004). Status of fish disease and health management practices in rural freshwater aquaculture of Bangladesh. Pakistan J. Biol. Sci. 7 (12): 2092-2098.
8. Masuda K. and Boyd CE (1993). Comparative evaluation of the solubility and algal toxicity of copper sulfate and chelated copper. Aquaculture 117: 287-302.

9. Reybrouck G (1998). The testing of disinfectants, Intl. J. Biodeterioration \& Biodegradation 41: 269-272.

10. McDonnell G and Russell AD (1999). Antiseptics and disinfectants: activity, action, and resistance. Clinic microb. rev. 12(1): 149-179.

11. Randall W, Oplinger and Wagner JE (2009). Toxicity of common aquaculture disinfectants to New Zealand Mud snails and mud snail's toxicants to Rainbow Trout eggs. North American J. Aqua.71:229-237.

12. Bolivar BR, Aragones DMA, Garcia G (2001). Effect of methylene blue and sodium chloride on the bacterial load in the transport water with Nile tilapia (Oreochromis niloticus) fingerlings. Health Management in Aquaculture. Southeast Asian Fish. Dev. Center, Philippines: 188-198.

13. Alderman DJ (1985). Malachite green: a review. J. Fish Dis. 8: 289-298.

14. Sudova E, Machova J, Svobodova Z and Vesely $T$ (2007). Negative effects of malachite green and possibilities of its replacement in the treatment of fish eggs and fish: a review. J. Vet. Med. 52(12):527-539.

15. Okpokwasili GC and Eleke FN (1997). Effect of antimicrobial agents on the activity and survival of Aeromonas hydrophilla and nitrifying bacteria in-vitro. J. Natn. Sci. 25(4):231-240.

16. Bills TD (1974). Toxicity of formalin, malachite green, and the mixture to four life stages of rainbow trout. Master's Thesis. University of Wisconson. 41pp.

17. Srivastava S, Sinha R and Roy D (2004). Toxicological effectsof malachite green. Aqua. Toxicol. 66: 319-329. 